\title{
IMPLICATION OF WEST LOMBOK REGULATION NO. 20 YEAR 2021 CONCERNING VILLAGE CHIEF ELECTION ON THE RIGHT TO VOTE AND BE ELECTED
}

\section{Agus Dedi Putrawan, Fauzi}

UIN Mataram

Mataram University

agusdediputrawan@gmail.com,Ojiqrm97@gmail.com

\begin{abstract}
Based on the principle of regional autonomy and the task of assisting the regions, they are given autonomous rights to regulate and manage their own households. Apart from that, regions are also given the right to make regulations that are in accordance with the needs of the region. The constitution must be contained in all types of regulations, both in the form of laws and regional regulations, so if they are not in accordance with these principles, the regulation can be canceled or null and void. West Lombok Regency has issued Regent Regulation No 20 of 2021 concerning the village Chief election with the delegation of authority from domestic government regulations 112 of 2014 concerning Village Chief Elections to further regulate in accordance with the conditions of the society in the area, in article 21 paragraph (2) of the Minister of Home Affairs Regulation in stipulates the candidate's requirements, namely "Be fearful of God Almighty" then added to regent regulation of the West Lombok in article 24 Paragraph (2) to "Be cautious of God Almighty and be able to read their respective holy books" but in the implementation stage, the regent regulation field this resulted in conflicts both occurring between the village chief election committee and the candidate for the village chief as well as with the community its self, as happened in Jembatan Kembar Timur Village, Lembar District, West Lombok and Taman Baru Village, Sekotong District, West Lombok.
\end{abstract}

Key Word: Village chief election, Principles, Regent regulation, West Lombok

\section{A. Introduction}

In article 1 paragraph (3) of the 1945 Constitution affirms that Indonesia is a state of law, this means that the implementation of government administration must be based on the provisions of the constitution and other laws and regulations, namely

POLITEA: Jurnal Politik Islam 
constitution, government regulations, regional regulations nor other legal provisions, which are determined democratically and constitutionally. ${ }^{1}$

Regional regulations are one of the instruments for local governments in carrying out their duties and authorities based on the regional autonomy system which gives the authority to manage and regulate all their own household affairs, including forming a regional regulation.

In article 18 paragraph (6) of the 1945 Constitution states that regional governments have the right to stipulate regional regulations and other regulations to carry out regional autonomy and assistance tasks. Based on these provisions, regional regulations are one of the supporting elements for the implementation of regional autonomy. In terms of politics and government, regional autonomy means selfgovernment or the condition of living under one's own laws. Thus, in regional autonomy, regions have self-own laws.

On the basis of the rights and powers granted by the state constitution to regions to regulate their own households and form blood regulations based on the principles of decentralization and co-administration, it is hoped that they will be able to fulfill the sense of justice and security of the people themselves.

herefore, West Lombok district government issued Regent Regulation No. 20 of 2021 concerning the village chief election and regent's regulation no. 23 of 2021 regarding amendments to the regent's regulation no. 20 of 2021 concerning the village chief election and the regent's regulation no. 26 of 2021 concerning the second amendment to the regent's regulation no. 20 of 2021 regarding the village chief election. The regulation is of course issued in hope that the process of implementing the village chief election can be run in an orderly, safe, honest and fair manner.

\footnotetext{
Yustisia Indonesia), HIm.14-15

${ }^{1}$ Surachmin, Azas dan prinsip Hukum Serta Penyelenggaraan Negara (Jakarta:Yayasan Gema 
However, later in the implementation stage, the Regent's Regulation on Village Chief Elections did not work as expected, conflicts occurred between the election committee and the village with prospective candidates also with the local community due to the vagueness of norms and violations of the principles of the formation of laws and regulations which is stated in Article 5 of Law Number 12 of 2011 in Chapter II concerning the Principles of Formation of Legislation.

The conflict occurred because the points in the article were still controversial and had multiple interpretations, thus the village chief election committee blundered in implementing the regent's regulation. The Regent's regulation is "fearful of God Almighty and able to read their respective holy books", these requirements became a core requirement so that many prospective village chief failed at the reading test stage of the holy book, both from noble descent and an ustadz in their village, the result of the failed test then make the dignity and worth as an honorable person must be lost and the candidate for the village chief must be prepared to bear the shame due to the failure of the reading test of the holy book.

So, to follow up on this matter, Lalu Mujitabe filed a lawsuit against the Election Committee for the Chief of the Jembatan Kembar Timur Village, Lembar districts to the Chairman of the Mataram Administrative Court on July 12, 2021, the object of the lawsuit includes:

1. Letter from the Chairperson of the Village Chief Election Committee, Jembatan Kembar Timur, Lembar District, West Lombok Regency, dated 072021 Number: 10/PPKD-JKMT/VI/2021, Subject: Expanation

2. Minutes of the results of the Reading holy book Test for Candidates for Village chief dated June 6, 2021, Number: 11/PPKD-JKMT/NI/2021

3. Minutes of the Administrative Selection of the Candidates for the chief of the Jembatan Kembar Timur Village, Lembar District, West Lombok Regency, dated June 072021 Number: 12/PPKD-JKMT/VI/2021. 
4. Minutes of Announcement of Examination Results/Requirements Documents of Candidates for Village chief of Jembatan Kembar Timur village, Lembar District, West Lombok Regency, dated 07 June 2021 Number: 13/PPKD-JKMT/VI/2021

The defendant's decision letter in this case is a written determination (beschikking) issued by the defendant who is authorized and is concrete, individual, and final which has legal consequences for a person and the interests of the defendant (Lalu Mujitabe) are greatly harmed. ${ }^{2}$

So that researchers are interested in investigating more deeply related to this case by comparing the regent regulation of the West Lombok Regent to the rules above it, especially laws no 12 of 2011 concerning laws and regulations because the legal principles of the regulations below must not against the law above, then the implications that occur in the field as a result of the enactment of the regent regulation on the sustainability of village chief elections.

\section{B. Methodology}

The type of research used by the researcher is normative legal research, which analyzes the reciprocal relationship between legal facts seen as independent variables and social facts seen as dependent variables. This research will depart from positive legal norms towards social facts that occur in the field.

\section{Discussion}

In article 21 of the Minister of Home Affairs Number 112 of 2014 concerning the Election of Village Chief, it has been regulated regarding the requirements for candidates for village heads and delegated authority to the regions to further regulate the requirements for candidates for village Chief, assistance along with further elaboration of the provisions of higher laws and regulations as regulated in Article 236 paragraph (1) of Law Number 23 of 2011 concerning statutory regulations.

This is the basis for the West Lombok Regent Regulation to further regulate the procedure for selecting village chief in accordance with community conditions, as

${ }^{2}$ Surat Gugatan Advokat Lalu Anton Hariawan, SH \&Partners, Lombok Barat, 12 Juli 2021

POLITEA: Jurnal Politik Islam

Vol. 4 No.2 Juli - Desember 2021

Agus, Fauzi IMPLICATION OF WEST.. 
well as the addition of the requirements for the election of village chief which are regulated in Article 24 of the West Lombok Regency Regulation Number 20 of 2021 concerning the Election of Village Chief. However, in terms of further regulation, it is not justified if the regulation departs from the norms and principles of establishing laws and regulations.

In terms of the formation of laws and regulations, Roscoe Pound states that the law as an element that lives in society must always advance the public interest. This means that the law must be born from the legal construction of the community so that all the interests of the community can be prioritized in its regulation. ${ }^{3}$ This is also in line with what was conveyed by Satjipto Rahardjo, namely humans are the determinants and points of legal orientation. The law is in charge of serving humans, not the other way around. Therefore, the law is not an institution that is separated from human interests, the quality of the law is determined by its ability to serve human welfare. ${ }^{4}$

According to the explanation above, Bagir Manan ${ }^{5}$ said that laws and regulations including regional regulations have internal functions and external functions, namely:

1. Stability function is regional regulations that function in the field of order and security which aims to ensure the stability of the people in the area.

2. The function of change is that regional regulations are formed to encourage changes in society and also good government officials with regard to work procedures, work mechanisms, and performance itself. Thus, regional regulations function as a means of renewal (law of social engineering).

3. The convenience function is local regulations can also be used as a means to regulate various facilities

\footnotetext{
${ }^{3}$ Roscoe Pound, An Introduction to the philosophy of law, ( Harvard:Yale University Press, 1954).

${ }^{4}$ Satjipto Rahardjo , Hukum Progresif

${ }^{5}$ Bagir Manan, Dasar-Dasar Perundang-Undangan Indonesia, (Jakarta:Ind-Hill Co. 1992)

POLITEA: Jurnal Politik Islam

Vol. 4 No.2 Juli - Desember 2021

Agus, Fauzi IMPLICATION OF WEST.. 


\section{Legal certainty function}

The concept of ideality regarding the laws and regulations above applies to all types of regulations in the statutory hierarchy, so if these principles conflict with the rules made then the rules can be canceled or null and void. Based on those regulations, this then become a touchstone to see the content of the West Lombok regent regulation Number 20 of 2021 concerning the Election of Village Chief.

The promulgation of regent regulation no 20 of 2021 concerning the Election of Village Chiefs is deemed not to be in accordance with legal norms and violates the applicable principles, in the material contained in the regent regulation in terms of the requirements for candidates for village chief as stated in Article 41 paragraph (2) " fear of God Almighty and be able to read their respective holy books" requiring prospective village heads to be "capable of reading holy books" is not in accordance with the principle of the formation of laws and regulations, namely the principle of clarity of purpose that every formation of legislation must have a purpose. Article 26 paragraph (1) of Law 6 of 2014 concerning Villages states that the village head is in charge of administering village government, carrying out village development, fostering village community, and empowering village communities.

A part from the principle of clarity of purpose, West Lombok regent regulation No.20 of 2021 concerning the Election of Village Chief is also seen as not in accordance with the principles of the laws and regulations contained in Article 6 of Law No. 12 of 2011 which emphasizes that the laws and regulations must reflect the principles of:

1. Protection, namely that every material contained in laws and regulations must function for protection to create public peace.

2. Humanity means that every material contained in laws and regulations must reflect the protection and respect for human rights as well as the dignity and worth of every citizen and resident of Indonesia proportionally. 
3. Nationality is that every material containing regulations and legislation must reflect the nature and character of the pluralistic Indonesian nation while maintaining the principles of the Unitary State of the Republic of Indonesia.

4. Familiarity means that every material contained in regulations and legislation must reflect deliberation to reach consensus in every decision-making.

5. Bhinneka Tunggal Ika means that the content of laws and regulations must pay attention to the diversity of the population, religion, ethnicity and class, special conditions of the region and culture in the life of society, nation and state.

6. Fairness that every material contained in laws and regulations must reflect justice proportionally for every citizen.

7. The equality of position in law and government is that any content material in laws and regulations may not contain discriminatory matters based on background, among others, religion, ethnicity, race, class, gender, or social status.

8. Order and legal certainty mean that every material contained in laws and regulations must be able to create order in society through guarantees of legal certainty.

9. Balance, compatibility and harmony are every material that must be contained in laws and regulations in carrying out the interest of individuals, society, and the interests of the nation and the State.

So, base on the issuance of the regent regulation, the community felt aggrieved and caused conflict between the village chief election committee and the village chief candidates, for example the case that occurred in the Jembatan Kembar Timur village, Lembar District and in Taman Baru Village, Sekotong District, West Lombok Regency where the village head candidates for not being able to read the holy book is required to back off from his candidacy as the Village Chief candidate referring to the West Lombok regent regulation no 20 of 2021 where they cannot reading their holy books. 
Let's review the case of the dispute over the election of village chief in the Jembatan Kembar Timur of Lembar District, Lalu Mujitabe is a descendant of Madya, this can be seen from his name "LALU". Madya is the second level in the Sasak tribal society where men have the title Lalu or Gede and the women have the title Baiq ${ }^{6}$. people who add the word "Lalu" to their first name are noble and respected people, this noble title is a special position that a person has because of his descendants who come from previous ancestors who have a higher degree than ordinary people ${ }^{7}$.

Then Lalu Mujitabe nominate himself as Village Chief in Jembatan Kembar Timur, in the process of screening candidates in Jembatan Kembar Timur who registered himself as many as 7 people and in the selection process 3 of them were failed, one of them was Lalu Mujitabe who was field due to not being able to read the holy book in front of the examiner team and 4 people are declared passed and elected directly by the people. The same case also happened in Taman Baru Village, the village is known for many religious figures, during the election season for the Village Chief, one of the Ustadz in Taman Baru village ran for village chief election but the same thing was experienced as the case in Jembatan Kembar Timur, the Ustadz had to resigned due to not being able to read the holy book Al-Qura'an in front of the village chief election committee.

This happened as a result of the nervousness of the village chief candidates when confronted by the village chief committee or the examiner team, because it was deemed impossible for people of noble descent and an ustadz to fail to read the holy book while in society they were already known as a believer because of their social way of life.

If viewed from the point of view of the previous principle, of course, with the issuance of the regent regulations, it has created conditions that do not reflect peace

\footnotetext{
${ }^{6}$ Lalu Tambeh Wadi, perbedaan stratifikasi sosial (Gelar Kebangsawanan) Sebagai Penyebab Terjadinya Pencegahan Perkawinan Persfektif Hukum Islam. AL-HIKAM Jurnal Ahwal Al-Syakhshiyah. Volume IX, Nomor 1,Juni 2017. HIm 2

${ }^{7}$ Ibid Hlm 6

POLITEA: Jurnal Politik Islam

Vol. 4 No.2 Juli - Desember 2021

Agus, Fauzi IMPLICATION OF WEST.. 
to the community and the dignity and worth as a candidate for village chied is lost due to the ambiguity of the norms in this regent regulation, and the requirement "Able to read the holy book" does not reflect the balance, compatibility and harmony between the interests of individuals, society, and the interests of the nation and the State.

To create balance, compatibility and harmony, the requirements for candidates to be "able to read scriptures" should not be a core requirement in the selection of prospective village head candidates, this requirement should be an additional requirement if the candidate for village head exceeds 5 (five) people because when viewed from the domestic government regulation No. 112 of 2014 that the maximum requirement for village head candidates is 5 people and if there are more than it the committee will make additional selections. So, if there are five candidates for village head, there is no need to test the ability to read scriptures.

\section{Conclusion}

Law Number 12 of 2011 concerning Legislation has regulated the hierarchy of laws and regulations from the 1945 Constitution to district/city regional regulations, besides that, it also regulates the principles of formation of laws and regulations that must be contained in the regulatory material, namely the principle of protection, humanity, nationality, kinship, archipelago, Bhineka Tunggal Ika, justice, equality, order and legal certainty, balance, compatibility and harmony.

However, with the promulgation of the West Lombok Regent Regulation Number 20 of 2021 regarding the village chief elections, it actually resulted in conflict because the points in the article were controversial, contrary to the principles that had been regulated in the formation of legislation, village chief election conflicts occurred at several points. in West Lombok, namely Jembatan Kembar Timuer, Lembar Subdistrict and Taman Baru Village, Sekotong Sub-district, from the two examples of conflict cases in the election of the Village chief because the Village chief Candidate 
failed in the selection stage for reading the holy books, and among those who failed in that stage were candidates for noble descent and an ustadz who were known as a well behaved in the community. Therefore, the requirement of "being able to read each other's holy books" is deemed inappropriate to serve as a core requirement in the selection of village chief candidates, it is more appropriate to be used as an additional requirement if there are more than five candidates for village chief elections.

\section{References}

Bagir Manan, Dasar-Dasar Perundang-Undangan Indonesia, (Jakarta:Ind-Hill Co. 1992) Lalu Tambeh Wadi, perbedaan stratifikasi sosial (Gelar Kebangsawanan) Sebagai Penyebab Terjadinya Pencegahan Perkawinan Persfektif Hukum Islam. ALHIKAM Jurnal Ahwal Al-Syakhshiyah. Volume IX, Nomor 1,Juni 2017.

Peraturan Menteri Dalam Negeri Nomor 112 Tahun 2014 Tentang Pemilihan Kepala Desa

Peraturan Menteri Dalam Negeri Nomor 12 Tahun 2014 Tentang Pemilihan Kepala Desa

Roscoe Pound, An Introduction to the philosophy of law, (Harvard:Yale University Press, 1954).

Surachmin, Azas dan prinsip Hukum Serta Penyelenggaraan Negara (Jakarta:Yayasan Gema Yustisia Indonesia),

Surat Gugatan Advokat Lalu Anton Hariawan,SH\&Partners, Lombok Barat, 12 Juli 2021 Undang-Undang Nomor 12 Tahun 2011 Tentang Peraturan Perundang-Undangan Yusnaini Hasyimzoem, M. Iwan Satriawan, Ade Arif Firmansyah, Siti Khoiriah, Hukum Pemerintahan Daera.Rajawali Pers. Devisi Buku Perguruan Tinggi.PT.Raja Grafindo Persada. DEPO.

POLITEA: Jurnal Politik Islam 
